\title{
Artificially extended photoperiod administered to pre-partum mares via blue light to a single eye: observations on gestation length, foal birth weight and foal hair coat at birth
}

Margaret B. Nolan ${ }^{\mathrm{a} 1}$, Caroline M. Walsh ${ }^{\mathrm{a}}$, Noelle Duff ${ }^{\mathrm{a}}$, Conor McCrarren ${ }^{\mathrm{a}}$, Barbara A. Murphy ${ }^{\mathrm{a}}$

\author{
${ }^{a}$ School of Agriculture and Food Science, University College Dublin, Belfield, Dublin 4, Ireland \\ cwalsh@winstarfarm.com; barbara.murphy@ucd.ie
}

Corresponding author: Margaret B. Nolan Email: margaret.nolan@up.ac.za

\section{Highlights}

- Pre-partum administration of blue light to a single eye may affect gestation length in the Thoroughbred mare.

- Pre-partum administration of blue light to a single eye affects foal weight at birth.

- Pre-partum administration of blue light to a single eye affects foal coat at birth.

\begin{abstract}
In seasonally breeding animals, photoperiod perception is crucial for timing of important physiological events. In the horse, long day photoperiod influences the onset of ovulation and cyclicity, shedding of the heavier winter coat and the timing of

\footnotetext{
${ }^{1}$ Present address: Veterinary Population Management Laboratory, Onderstepoort, University of Pretoria, Pretoria, 0110, South Africa
} 
parturition. In this compilation of studies, conducted across three breeding seasons and two countries, the impact of artificially extended day length was investigated on gestation length, foal birth weight and foal hair coat at birth. The light therapy was administered to pre- partum mares via mobile head worn masks which provided short wavelength blue light to a single eye. In Study 1, reductions in gestation lengths were observed following administration of artificially extended day length (124.8 \pm 15.11 days) in the final months of pregnancy to a group of Thoroughbred mares compared to controls $(P<0.05 ; 339.7 \pm 9.56$ days vs $350.6 \pm 9.13)$. Study 2 revealed that pre-partum exposure to artificially extended day length (104.6 \pm 9.89 days) increased foal birth weight compared to controls $(47.13 \pm 2.93 \mathrm{~kg}$ vs $43.51 \pm$ $6.14 \mathrm{~kg} ; \mathrm{P}<0.05)$ in mares bred early in the year. In Study 3, artificially extended day length (87.53 \pm 19.6 days) administered to pre-partum mares affected the coat condition of foals at birth with respect to hair weight $(P<0.0001)$ and hair length $(P<$ $0.0001)$ compared to controls $(0.34 \pm 0.20 \mu \mathrm{g}$ vs $0.59 \pm 0.12 \mu \mathrm{g}$ and $1.93 \pm 0.56 \mathrm{~cm}$ vs $2.56 \pm 0.32 \mathrm{~cm}$, respectively). Collectively, these studies serve to highlight the influential role of the circa-annual changes in photoperiod length on the pre-partum mare for normal foetal development during the natural breeding season. It also emphasizes the potential that exists to improve breeding efficiency parameters by artificially simulating this important environmental cue in the latter stages of gestation against the backdrop of an economically driven early breeding season.

\section{Keywords}

pre-partum, photoperiod, gestation length, blue light, birth weight, hair coat 


\section{Introduction}

The domestic horse mare (Equus caballus), as a seasonal breeder, has an endogenous circa-annual reproductive rhythm and the main role of seasonal cues appears to be to synchronize the endogenous rhythm to winter and summer [1]. The natural physiological breeding season occurs approximately from April to September in the northern hemisphere and is stimulated by increases in day length, temperature and food availability [2]. The primary regulator is the increased daylight hours associated with spring that provide a seasonal cue for reactivation of the hypothalamic-pituitary-ovarian axis via reductions in melatonin secretion from the pineal gland [3]. The exposure to artificial light to extend day length to approximately $16 \mathrm{~h}$ total during winter is a common management tool on commercial horse breeding farms to advance seasonal reproductive activity [4]. When started in early December, this regime successfully advances the onset of ovarian activity in the non-pregnant mare [5] and allows breeders to meet industry imposed breeding timelines and a market demand for foals born earlier in the year created by the arbitrary January 1 birth date for many horse breeds. A common observation of lighttreated mares is early shedding of the heavier winter coats [6]. Photoperiod is known to exert a dominant influence on seasonal pelage and there is significant evidence to demonstrate that prolactin is involved [7].

Recent research indicates that short wavelength light within the blue spectrum is particularly effective at suppressing melatonin secretion in the horse [8]. Studies in Thoroughbreds have shown that melatonin can be suppressed to daytime levels using low-intensity blue light (468 $\mathrm{nm}$ ) from light emitting diodes (LED) directed at a single eye and has been used to effectively advance the ovulatory season of the mare $[8,9]$. 
Similar to other seasonally breeding animals $[10,11,12]$, photoperiod is also important for the pregnant mare. Gestation lengths have been found to decrease as the natural foaling season progresses and the daily length of daylight gets longer $[13,14,15]$. Links between increasing daylight hours and concurrent decreases in gestation lengths were first reported in 1938 [16] and have since been supported by further studies $[17,18]$. The first study to investigate the effect of artificially extended photoperiod on pregnant mares reported a significant shortening of gestation length and a trend towards higher birth weights [19]. Moreover, photoperiod changes have been linked to variability in the gestation length of deer [11, 12]. This provides support for the suggestion by Perez et al. [14] that light to the pregnant mare may modify the rate of foetal maturation during the final trimester.

Foal birth weight is an important factor for horse breeders as it has been found to correlate to the weight and size of the horse as a yearling [13] and therefore has a perceived influence on a horse's potential earnings and future athletic ability. Foals born later in the year (April, May and June), during the natural breeding season for the horse, have comparably higher birth weights than foals that are born in January, February and March [13]. This increase in birth weight has been shown to correlate with a decrease in gestation length $[13,14,15]$.

Consequently, three studies were conducted across three breeding seasons in Ireland and KY, USA to determine if long- day photoperiodic stimulation of mares during the final third of gestation using mobile blue light directed at one eye influenced gestation length, foal birth weight and foal coat at birth. 


\section{Materials and Methods}

All animal experiments complied with the ARRIVE guidelines and were carried out in accordance with the U.K. Animals (Scientific Procedures) Act, 1986 and associated guidelines, EU Directive 2010/63/EU for animal experiments (Study 1 and Study 3), and the National Institutes of Health guide for the care and use of Laboratory animals (Study 2; IACUC 2012-0928)

\subsection{Study 1 - Ireland - Gestation Length}

\subsubsection{Animals and Environment}

Fifteen pregnant Thoroughbred mares (Equus caballus), ranging in age from 5 to 18 (12 \pm 4.19$)$ years, with a history of prolonged gestation lengths (mean gestation length of 350 days for previous gestations where available) were used in a study conducted from December 1, 2011 through May, 2012 on a single commercial Thoroughbred breeding farm located in Kildare, Ireland at longitude W 54.51 and latitude N 9.22. The natural day length at the beginning and end of the study period was $8 \mathrm{~h} 01 \mathrm{~m}$ and $16 \mathrm{~h} 30 \mathrm{~m}$, respectively, with a temperature range of 2.5 to $16.4^{\circ}$ C.

All mares were maintained at pasture during the day and in individual stalls at night during the study period. All mares grazed ad libitum during the day and had ad libitum access to hay during the night. The mares' diets were supplemented with a commercially prepared concentrate feed mix according to their individual requirements as assessed by farm management and in accordance with feed manufacturer guidelines. Access to water was ad libitum at all times. Beginning on December 1 , Group $1(n=6)$ received individual light therapy from head worn masks (Equilume® Light Masks, Equilume Ltd., Kildare, Ireland) that provided 50 lux of blue 
light $(468 \mathrm{~nm})$ to the right eye. The light turned on at 16:30 each day and turned off at $23: 00$ nightly, providing an initial $14.5 \mathrm{~h}$ day, gradually increasing to a maximum day length of $16 \mathrm{~h} 15 \mathrm{~min}$ as the natural hours of daylight advanced.

Group $2(n=9)$ continued to be maintained under lighting conditions that reflected the natural photoperiod for the time of year at this location.

Records were collected following parturition for each mare and foal. These included; sire of foal, sex of foal, weight of foal within $12 \mathrm{~h}$ of birth (where available), gestation length, historical gestation lengths for two previous breeding seasons (where available), mare age and parity. Gestation length was calculated as the number of days from date of last breeding to date of parturition.

\subsubsection{Statistical Analysis}

For each Group, the mean and SD were calculated for number of days in foal at initiation of treatment, number of days from initiation of treatment to parturition, gestation length and foal birth weight for each resulting foal. Data were analysed using a Mixed Model in Graph Pad Prism Version 7.01 for Windows (Graph Pad Software, San Diego, CA, USA). In the Mixed Model, parity, age of mare, and sex of foal were considered as fixed effects and mare within treatment was treated as a random effect. A paired T test was used to compare the gestation length of five mares in Group 1 with the average gestation from their previous two gestations. Data are presented as means \pm SD. P-values $\leq 0.05$ are considered statistically significant. Statistically significant results are presented graphically. 


\subsection{Study $2-K Y-$ Gestation Length and Foal Birth Weight}

\subsubsection{Animals and environment}

Twenty-nine pregnant light breed mares, ranging in age from 5 to $18(9.8 \pm 4.3)$ years and their subsequent offspring were used in a study conducted from December 1, 2012 through April 30, 2013 on a single institutional research farm in KY, USA at longitude N 37.5, latitude $\mathrm{W} 85$. The natural day length at the beginning and end of the study period was 9 h $44 \mathrm{~m}$ and $12 \mathrm{~h} 53 \mathrm{~m}$ respectively, with a temperature range of -7 to $26^{\circ} \mathrm{C}$. In the preceding season, all mares were inseminated with mixed semen collected from two Quarter Horse stallions ( $X$ and $Y$ ) between the period March 23 and April 28, 2012. All subsequent foals were born in the period from February 18 to April 6,2013 . Of the 29 foals born, 25 were born in March 2013.

The mares were divided into two groups and blocked for age, parity, body condition score (BCS) and bodyweight. Beginning December 1, Group $1(n=15)$ received an artificially extended photoperiod using 50 lux blue light (468nm) directed at a single eye from dusk until 23:00 daily via individual head worn commercially available light masks (Equilume Ltd, Kildare, Co. Kildare, Ireland). Group $2(n=14)$ were maintained under natural photoperiod. All mares were maintained outdoors in two large paddocks with ad libitum access to hay and water and each mare received $1.4 \mathrm{~kg}$ of mare nuts (Winchester Feed \& Supply, KY, USA) once a day. Gestation length was calculated as the number of days from insemination to parturition. FBW in $\mathrm{kg}$ was measured within $24 \mathrm{~h}$ of birth using a freestanding animal weighbridge (HorseWeigh®, Kentucky, USA). Paternity testing was conducted on all foals 
following birth using a commercial Equine Parentage Test based on hair follicle DNA typing at the Animal Genetic Testing \& Research Laboratory, University of Kentucky.

\subsubsection{Statistical Analysis}

The mean and SD were calculated for the number of days in foal at initiation of assigned treatment, the number of days from initiation of treatment to parturition, gestation length of all mares and foal birth weight for each resulting foal. Data was analysed using a Mixed Model in Graph Pad Prism Version 7.01 for Windows (Graph Pad Software, San Diego, CA, USA). In the Mixed Model, parity, age of mare, mare body weight, BCS of mare and sex of foal were considered as fixed effects and mare within treatment was considered a random effect. Correlation analysis was conducted for mare birth weight and foal birth weight. Data are presented as means \pm SD. P-values $\leq 0.05$ are considered statistically significant. Statistically significant results are presented graphically.

\subsection{Study 3}

\subsubsection{Animals and Environment}

Forty-six pregnant Thoroughbred mares ranging in age from 5 to $23(10.2 \pm 5)$ years and subsequent offspring were used for a study conducted from November 2014 through April 2015 on a single commercial Thoroughbred stud farm in Kildare, Ireland at longitude N 53.1667, latitude W 6.7500. The natural day length at the beginning and end of the study period was $8 \mathrm{~h} 17 \mathrm{~m}$ and $14 \mathrm{~h} 38 \mathrm{~m}$ respectively, with a temperature range of -4 to $17^{\circ} \mathrm{C}$. All mares were maintained in outdoor paddocks with ad libitum access to hay and water. The mares' diets were supplemented with a commercially prepared concentrate feed mix according to their individual requirements as assessed by farm management and in accordance with feed 
manufacturer guidelines. Group 1 mares $(n=19)$ were fitted with commercially available light masks (Equilume Ltd.) on Nov 24th. The light masks provided 50 lux of blue light $(468 \mathrm{~nm})$ to a single eye from dusk until 23:00 nightly, providing an initial $14.5 \mathrm{~h}$ day, gradually increasing to a day length greater than $16 \mathrm{~h}$ as environmental sunrise time changed.

Group $2(\mathrm{n}=27)$ were matched for age and expected foaling dates and were maintained under natural photoperiod. All mares were housed at night when physical signs of imminent parturition were observed. A hair sample, complete with hair follicles, was pulled from the shoulder area of all foals within $48 \mathrm{~h}$ of birth. Three hairs from each sample were measured for length in $\mathrm{cm}$ and the average calculated. Ten hairs from each sample were weighed using a scale that measured in $\mu \mathrm{g}$.

\subsubsection{Statistical Analysis}

T-tests were conducted to determine if significant differences existed between group means for length and weight of hair. Statistical analysis was conducted using GraphPad Prism Version 7.01 for Windows (Graph Pad Software, San Diego, CA, USA). Data are presented as means \pm SD. P-values $\leq 0.05$ are considered to be statistically significant. Statistically significant results are presented graphically. A Pearson Correlation analysis was conducted for all data collected.

\section{Results}

\subsection{Study 1}

The number of days in foal at the initiation of treatment was $214.8 \pm 11.58$ and 259.8 \pm 20.84 for Group 1 and Group 2 respectively $(P<0.001)$. The number of days of 
assigned treatment protocol from initiation of the treatment (December 1, 2011) to parturition was $124.8 \pm 15.11$ and $90.78 \pm 20.77$ for Group 1 and Group 2 respectively $(P<0.01)$. No difference existed between the sex ratios in subsequent foals in each group $(P=0.55)$

\subsubsection{Gestation length}

Group $1(n=6)$ demonstrated a mean gestation length of $339.7 \pm 9.56$ days. Group 2 $(n=9)$ demonstrated a mean gestation length of $350.6 \pm 9.13$ days. A mean difference of $10.89 \pm 4.9$ days $(\mathrm{P}<0.05$; Figure $1 \mathrm{a}$ ) was observed between groups. A second statistical comparison was made between the gestation lengths of five mares from Group 1 and the mean of their two most recent previous gestation periods. Following an artificially extended day length in 2012, a mean gestation length of $334.6 \pm 3.669$ days was observed compared to a mean previous gestation length of $347.8 \pm 3.541$ days. This represents a mean difference of $13.2 \pm 5.099$ days $(P<0.05$; Figure $1 b)$.

\subsubsection{Foal birth weight}

There was no difference in the mean foal birth weight of foals from mares in Group 1 $(49.3 \pm 3.9 \mathrm{~kg})$ and mares in Group $2(54.9 \pm 5.93 \mathrm{~kg})(P>0.05)$.

\subsection{Study 2}

The number of days in foal at the initiation of assigned treatment protocol was 242.8 \pm 10.42 days and $243.1 \pm 11.66$ days for Group 1 and Group 2 respectively $(\mathrm{P}>$ 0.05). The number of days of assigned treatment from initiation (December 1, 2012) to parturition was $104.6 \pm 9.89$ and $106.4 \pm 14.62$ days for Group 1 and Group 2 respectively $(P>0.05)$. No difference existed in the proportion of foals sired by stallion X (Group 1; 11/15, Group 2; 12/14) and stallion Y (Group 1; 4/15, Group 2; 
$2 / 14)$ between groups $(P>0.05)$. No difference existed between the sex ratios in subsequent foals in each group $(P>0.05)$.
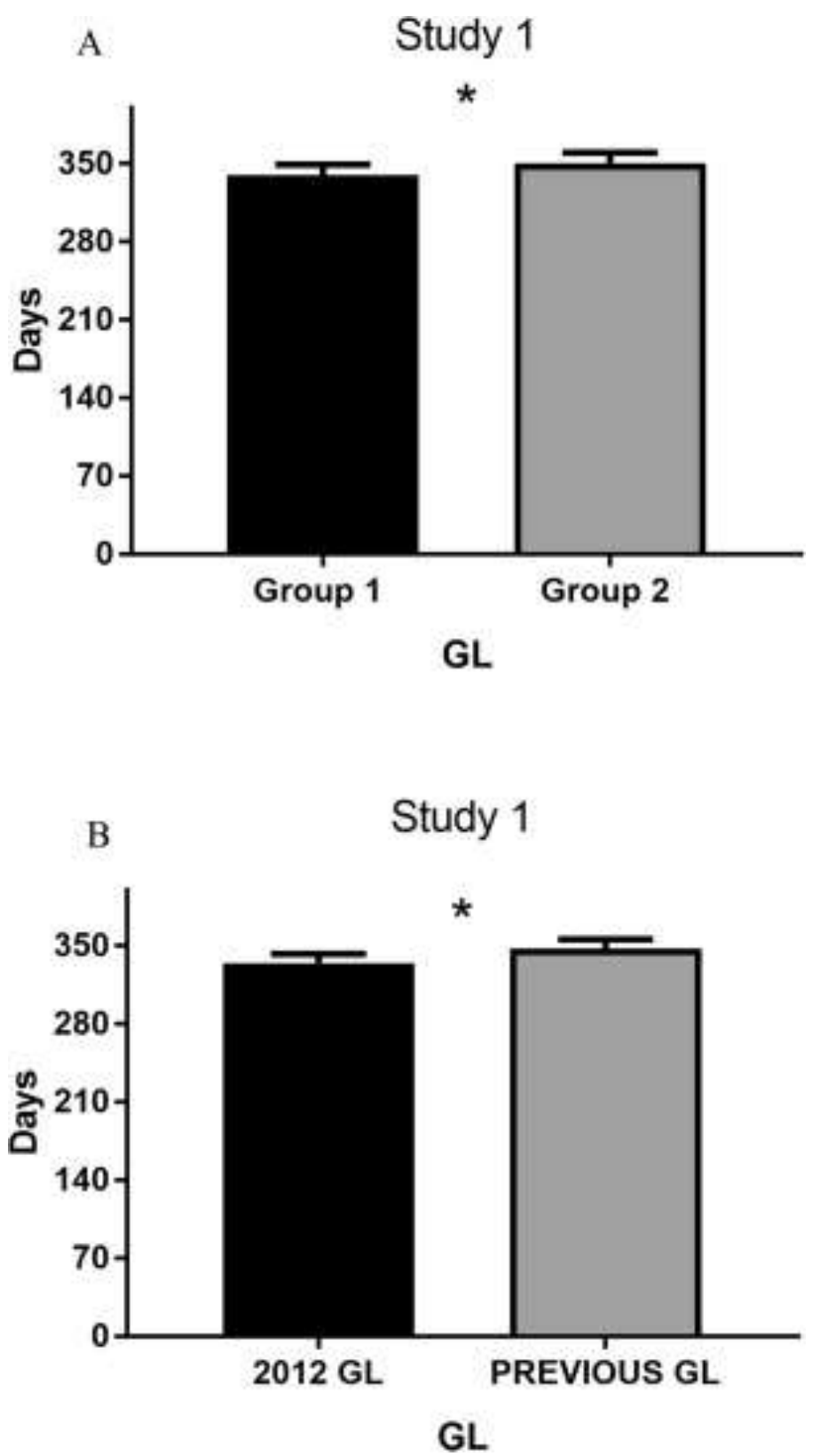

Figure 1a. Influence of pre-partum extended day length using blue light to one eye on gestation length in Thoroughbred mares: mean gestation length in days for Group 1 (treatment) and Group 2 (control). * denotes $\mathrm{P}<0.05$

Figure 1b. Influence of pre-partum extended day length using blue light to one eye on gestation length in Thoroughbred mares: mean gestation length in days for Group 1 (treatment) in 2012 and mean previous gestation length of same mares. * denotes $\mathrm{P}<0.05$ 


\subsubsection{Foal birth weight}

The mean foal birth weight of Group 1 was $47.13 \pm 2.93 \mathrm{~kg}$. The mean foal birth weight of Group 2 was $43.51 \pm 6.14 \mathrm{~kg}$. This represented a mean difference of 3.64 $\pm 1.77 \mathrm{~kg}(\mathrm{P}<0.05 ;$ Figure 2$)$.

\section{Study 2}

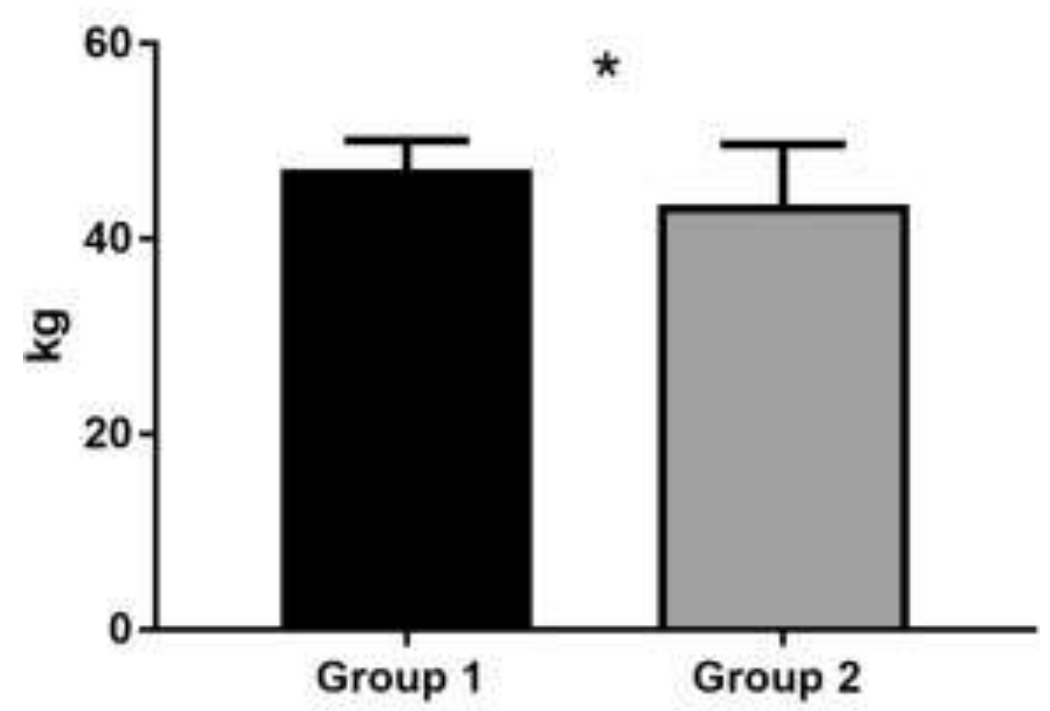

FBW

Figure 2. Influence of pre-partum extended day length using blue light to one eye on foal birth weight: mean foal birth weight in kg for Group 1 (treatment) and Group 2 (control). * denotes $\mathrm{P}<0.05$

Within each group, no differences were observed for foal birth weight between male and female foals $(P>0.05)$. When comparisons were made between treatment groups for male and female foals independently, no differences were noted $(P>$ 0.05 , respectively).

The mean mare birth weight in Group 1 and Group 2 at the beginning of the study period was $572.4 \pm 64.95$ and $565.9 \pm 57.45 \mathrm{~kg}$, respectively. The correlation coefficient $(r)$ for mare birth weight at the beginning of the study period and foal birth 
weight in Group 1 and Group 2 was $0.43(P>0.05)$ and $0.085(P>0.05)$, respectively. No correlation was noted between mare birth weight and foal birth weight. No data was available for mare birth weight at the time of, or following parturition.

\subsubsection{Gestation length}

Mean gestation length did not differ between Group 1 and Group $2(P>0.05 ; 345.67$ \pm 8.82 and $349.5 \pm 10.77$ days, respectively). Within Group 1 and Group 2 no differences were observed for gestation length for male and female foals $(P>0.05$, respectively). Similarly, between groups, no differences were observed for gestation length for male and female foals $(P>0.05$, respectively).

\subsection{Study 3}

The number of days in foal at the initiation of treatment was $251.9 \pm 20.59$ and 247.4 \pm 21.74 days for Group 1 and Group 2, respectively $(P>0.05)$. The number of days of assigned treatment from initiation of the treatment (November 24, 2014) to parturition was $87.53( \pm 19.6)$ and $97.44( \pm 20.01)$ days for Group 1 and Group 2, respectively $(P>0.05)$. There was no difference between the sex ratios in subsequent foals in each group $(P>0.05)$.

\subsection{Hair weight}

Mean hair weight in Group 1 and Group 2 was $0.34 \pm 0.20$ and $0.59 \pm 0.12 \mu \mathrm{g}$, respectively $(P<0.0001$; Figure 3a and Figure 4). Within each group, no differences were found for hair weight between male and female foals ( $P>0.05$, respectively). Comparisons made between Group 1 filly foals and Group 2 filly foals demonstrated differences in hair weight $(P<0.0001)$. Comparisons made between Group 1 colt 
foals and Group 2 colt foals demonstrated differences in hair weight $(P<0.01)$. Both colt and filly foals in Group 1 had significantly lower hair weights.
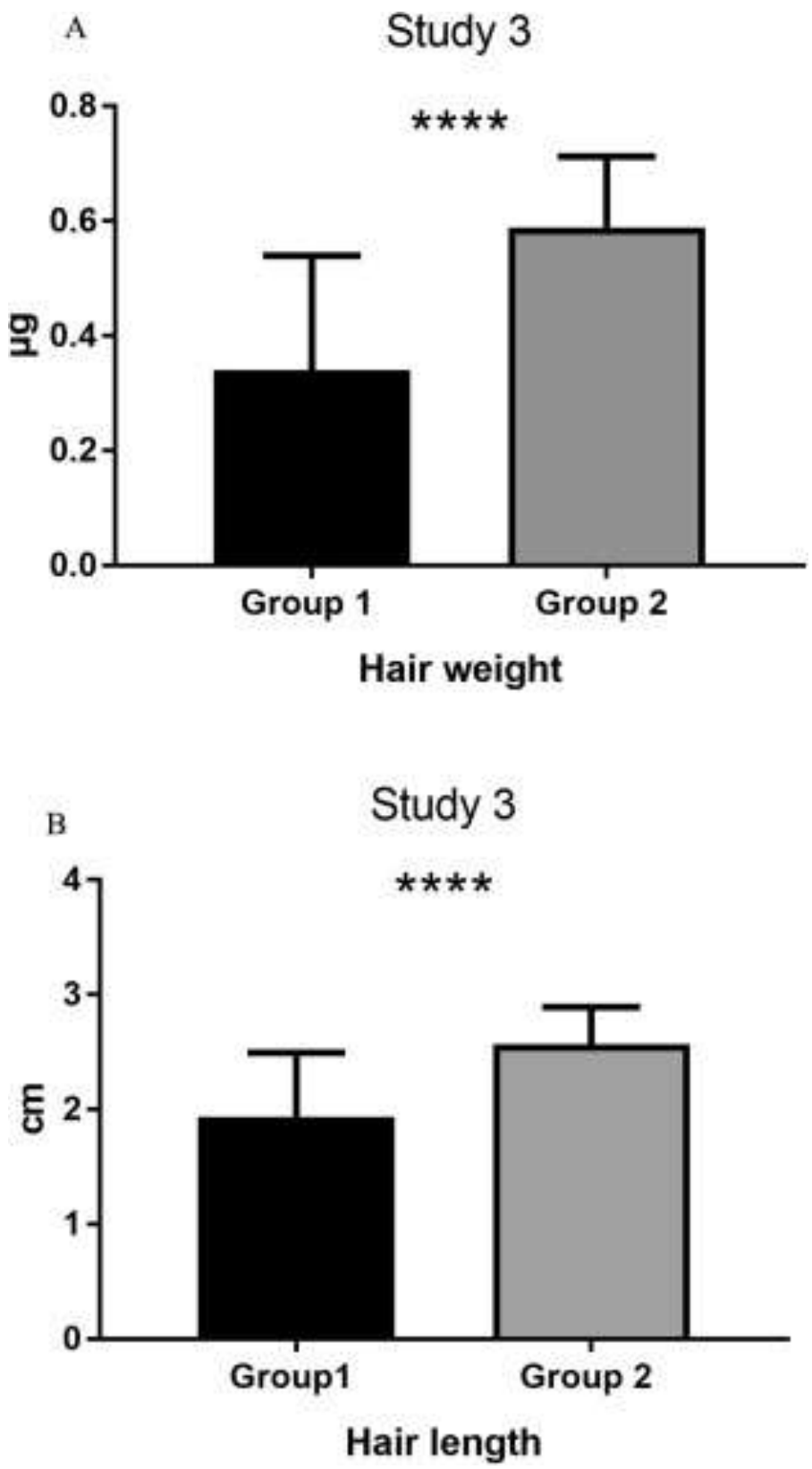

Figure 3a. Influence of pre-partum extended day length using blue light to one eye on foal hair coat: mean foal coat hair weight in $\mu \mathrm{g}$ for Group 1 (treatment) and Group 2 (control). ${ }^{* \star * *}$ denotes $\mathrm{P}<$ 0.0001

Figure 3b. Influence of pre-partum extended day length using blue light to one eye on foal hair coat: mean foal coat hair length in $\mathrm{cm}$ for Group 1 (treatment) and Group 2 (control). ${ }^{* \star \star *}$ denotes $\mathrm{P}<$ 0.0001 


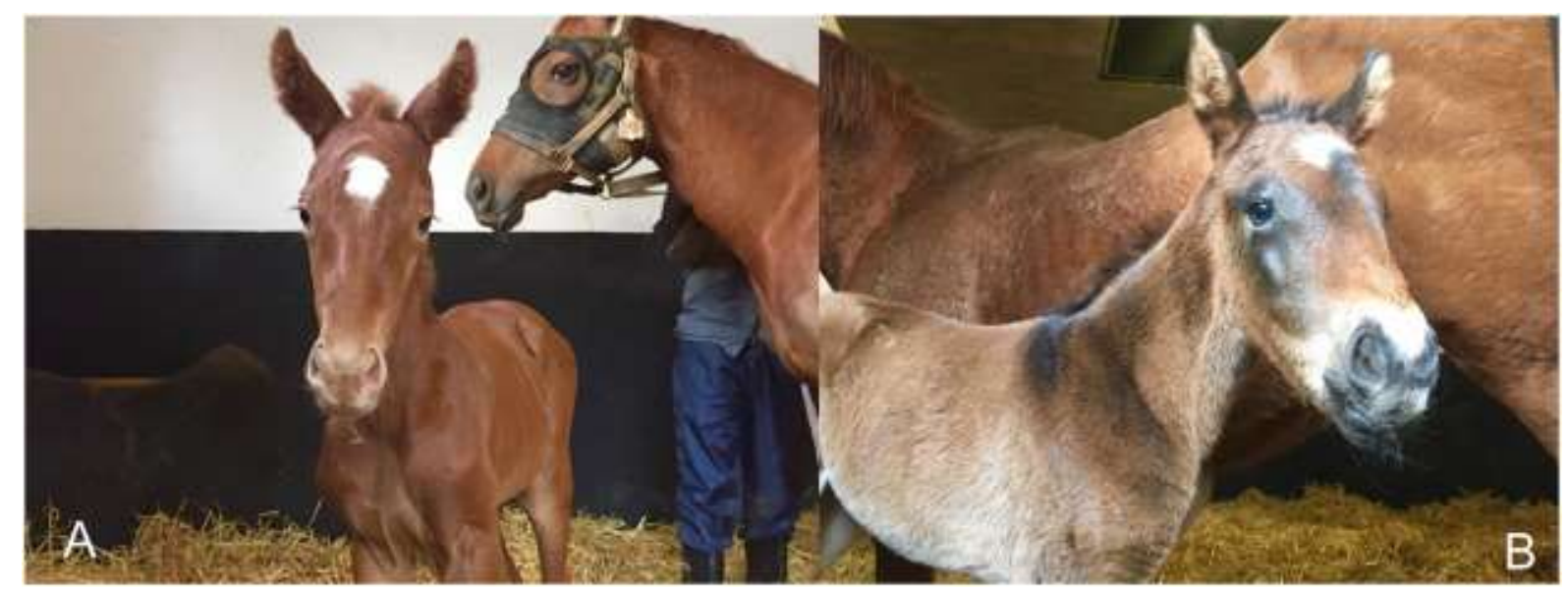

Figure 4. Influence of pre-partum extended day length using blue light to one eye on foal hair coat: Images $\mathrm{A}$ and $\mathrm{B}$ are taken within $24 \mathrm{~h}$ of birth of two colt foals born on the same day from Group 1 and Group 2, respectively. Clear differences in hair coats can be observed.

\subsubsection{Hair length}

Mean hair length in Group 1 and Group 2 was $1.93( \pm 0.56)$ and $2.56( \pm 0.32) \mathrm{cm}$ respectively $(P<0.0001$; Figure $3 b$ and Figure 4$)$. Within each group, no differences were found for hair weight between male and female foals $(P>0.05$, respectively). Comparisons made between Group 1 filly foals and Group 2 filly foals demonstrated significant differences in hair length $(P<0.01)$. Comparisons made between Group 1 colt foals and Group 2 colt foals demonstrated significant differences in hair length ( $P$ $<0.01)$. Both colt and filly foals in Group 1 had significantly shorter hair length. A positive correlation was demonstrated between hair length and hair weight $(r=0.83, P$ $<0.0001)$ in Group 1. A correlation matrix was compiled to assess the associations between coat growth dynamics and all other variables and is available as supplementary material. 


\section{Discussion}

\subsection{Influence of pre-partum extended day length using blue light to one eye on gestation length in Thoroughbred mares}

In the Thoroughbred industry, where a breed wide universal birth date sets a standard that encourages the production of foals early in the year, prolonged gestation length has clear economic implications. The present study suggests that by exposing pregnant mares to low intensity short wavelength blue light from December 1 , it is possible to shorten the gestation length of a Thoroughbred mare who has previously demonstrated a prolonged gestation period. It is possible that these mares may have conceived earlier in previous years and that this contributed to longer gestations. The study compared gestation lengths of mares that received mobile light therapy with both a control group of mares who foaled in the same year but did not receive light therapy and with the previously recorded gestation lengths of the same mares. The first comparison uses a control group and accounts for variables such as sex of foal, mare age and parity which would not have been possible when comparing the same group of mares to their own reproductive history. The second comparison does not account for these factors which have been previously reported to affect gestation length $[14,15,21]$ but does provide the benefit of repeated measures from the same mares, which in itself reduces variability as it is known that there is a genetic contribution to gestation length [15] and therefore consistency in gestation length throughout the production lifetime of a broodmare. Nevertheless, both comparisons revealed a similar shortening of gestation in days. In itself, the authors consider this a preliminary study with promising results indicating the potential for a future study with a larger number of replicates. Additionally, the differences between groups in treatment duration and days in foal at the initiation of 
the study period may have represented an important source of variation and should be avoided for future investigations. This study recorded gestation length as date of last service to date of parturition. As such, future studies may achieve greater gestation length accuracy if gestation length is calculated from day of ovulation to parturition. However this timing is seldom recorded on commercial farms. The gestational age (days in foal) at initiation of treatment should also be determined in future studies, since this parameter appears to play an important role.

Notwithstanding study limitations, the results do support previous conclusions that extended photoperiod influences gestation length in the mare $[14,16,19]$. It is also indicated that this benefit may be achieved in pre-partum mares using a mobile light therapy device whereby timed blue light is administered to a single eye. This technology may help prevent the prolonged gestation lengths that are commonly observed on Thoroughbred farms early in the breeding season, especially in aged mares [22]. The proposed mechanism of action is early activation of the somatotrophic axis by advancing the summer photoperiod $[28,29]$ stimulating foetal growth in utero as well as changing the hormonal milieu in the mare in preparation for parturition and lactation [19, 30, 34].

\subsection{Influence of pre-partum extended day length using blue light to one eye on foal birth weight}

This study demonstrates a significant influence of pre-partum extended day length photo stimulation on foal birth weight. A study investigating foal birth weight is not particularly informative when conducted on a commercial breeding farm where a high number of different sires are used and genetically contribute to wide variation in the physical traits of the offspring between mares. Sire effect was controlled for in this study by inseminating mares with the same semen mix from two stallions and 
subsequently DNA fingerprinting the resulting foals. It was shown that a single stallion sired most of the foals. This likely helps to explain why there was no difference observed for foal birth weight in Study 1, where many different sires with differing physical traits were used. A second advantage of a more controlled study is that timing of insemination of the mares spanned a single month, permitting a comparison of treatment effect in mares of the same gestational age.

In contrast to Hodge et al. [19] and Study 1 described here, no difference in gestation length was observed. This may be explained by the different reproductive histories of the groups of mares used and/or the difference in gestational age at initiation of treatment. In the current study, over $50 \%$ of the mares were in foal for the first time. Maiden foaling mares are reported to have greater gestation length variability $[15,21,23,24]$. Secondly, there were a higher proportion of younger mares in this study and lengthened gestations are correlated with increasing age [15].

An extended photoperiod simulating that of summer time is likely responsible for the delivery of a time of year message to the developing foetus, either directly via melatonin crossing to the foeto-placental unit and binding to foetal melatonin receptors [25], or indirectly via changing endocrine profiles in the mare. Although the exact mechanism has not been elucidated, it has been suggested that variations in day length could represent signals by which the mare regulates late term development of the foetus [23].

Melatonin receptors have been found in the early gestational foetal tissue of red deer and sheep $[26,27]$ which could indicate a direct pathway for photoperiod signals from the mother in foetal development. Studies have shown that melatonin is rapidly 
transferred across the placenta and blood brain barrier and that daily changes in maternal melatonin concentration would be precisely reflected in the foetus [25].

Growth rate, size and certain adaptations to environmental conditions are regulated primarily by the somatotrophic axis $[28,30,31]$. The two main components of which are growth hormone (GH) and its effector, insulin-like growth factor 1 (IGF-1) [31]. These act as regulatory factors in skeletal growth [30]. Multiple studies have confirmed the clear seasonal patterns in IGF-1 concentrations in the horse [30, 32, 33]. When assessing IGF-1 concentrations in growing Thoroughbred foals it was noted that the highest values occurred in May and June and the lowest in March in the northern hemisphere [34]. Positive associations between growth, IGF-1 concentrations and environmental conditions have been reported in cattle, deer and pigs $[35,36,37]$. Combined, these studies demonstrating the connection between environmental conditions and growth rate, as controlled by the somatotrophic axis, support the concept of growth regulation by changing photoperiod [38]. There is also direct evidence that melatonin plays a role in the regulation of $\mathrm{GH}$ secretion in some species [39]. If the equine foetus is similarly influenced by the circulating levels of melatonin in the mare, the duration of which is regulated by her light exposure, this may stimulate the somatotrophic axis in the foal to regulate growth. Thus, this could serve to explain how artificial light therapy influences foal birth weight and how increased foal birth weights are associated with summer time breeding. The increased foal birth weight reported here in foals from pre-partum photo stimulated mares may be a response to earlier activation of the somatotrophic axis.

Interestingly, it was recently shown that decreasing daylight affects reindeer gestation length by down regulating foetal growth at a time when perceived food 
availability decreases [20]. It is postulated therefore that increasing daylight conversely up regulates foetal growth in the horse in anticipation of an amenable environment for development of young stock.

\subsection{Influence of pre-partum extended day length using blue light to one eye on foal hair coat.}

In this study, we show for the first time that artificial photoperiodic stimulation of the pre-partum mare influences pelage in the resulting offspring with respect to hair length and weight. It also demonstrates the multicollinearity of hair weight and length in the coat of foals from mares that received an artificially extended day length in late pregnancy. While the influence of light and the role of prolactin on hair growth and molting has been studied in animals that are directly exposed to artificial light $[40,41$, 42,43 , little if any research exists on the transmission of the environmental signal to the developing foetus. By living inside the maternal compartment, the foetus is predictably exposed to rhythms of the mare's internal milieu such as temperature and endocrine profiles, with melatonin, one of the few maternal hormones known to cross the placenta unaltered [25]. Information in relation to delivery and transport of other hormones within maternal and foetal compartments is limited, although a few members of the prolactin and GH families have been reported to enter mammalian foetal circulation $[44,45]$. While it was not possible to measure maternal or foetal serum prolactin levels in this study, it was previously reported that prolactin concentrations fluctuate with an unclear pattern during pregnancy in the mare [46]. However, the lack of a perceptible prolactin pattern observed previously [46] may have been due to omitting to take into account the prevailing photoperiod length (time of year) relative to pregnancy stage in that study. 
The reduction in melatonin production during the lengthening days of spring and summer stimulates increased circulating prolactin concentrations [47]. Photoperiod, translated to a pineal-melatonin output, is a known environmental cue involved in the regulation of prolactin production in the mare [40]. Studies in other species have shown that the perception of a short day, achieved via exogenous administration of melatonin, is associated with a decrease in prolactin production $[48,49]$. We propose that the results observed in the current study are due to increased prolactin production in the mare in response to the long day photoperiodic stimulus provided by the administration of low intensity blue light to one eye and a consequent suppression of melatonin [8]. Melatonin in the horse is produced during darkness and is acutely responsive to changes in the light - dark cycle [50].

Studies have shown that prolactin plays a key role in the hair growth cycle, particularly during the catagen stage [51]. This is a transitional phase in the hair growth cycle during which growth stops. It is postulated that increasing circulating prolactin concentrations in the mare also exert effects on the developing foetus. The exact mechanism by which this occurs has not yet been elucidated but candidate pathways exist. For example, it has been shown that the mammalian foetus develops in an environment where prolactin is present and it is hypothesised that, like other species, the equine foetus also develops receptors for prolactin [26, 27, 52]. There is evidence that prolactin and melatonin receptors are present in the equine placenta. Therefore, if the foetus is exposed to higher prolactin levels via maternal circulation, as occurs naturally from April to July [40], then we assert that the developing hair follicles will spend more time in catagen and so will be significantly shorter [51] and thus lighter. Confirmation of the presence of prolactin 
receptors on the equine foetus is necessary to provide further support for this mechanism.

A study carried out by Gebbie et al. [41], suggested that the effects of prolactin on hair growth are strongly related to environmental temperature. It was suggested that increases in temperature acted to reinforce the effects of an increase in prolactin [41]. However, unlike the ex utero adaptive physiological responses to environmental temperature changes for altering pelage, the foetus is exposed solely to the warm core body temperature of the mare, with only slight $24 \mathrm{~h}$ circadian fluctuations [53]. Thus, we suggest that any potential exposure to increased maternal prolactin likely has a more pronounced effect on hair growth in utero.

This study demonstrates a significant effect of extended photoperiod on foal birth coat when administered to the pre-partum mare during the final third of gestation. Furthermore, we show that this photo stimulatory effect can be achieved using lowintensity blue light to one eye. The exact mechanism of action is to be elucidated. We hypothesize that photoperiodic suppression of melatonin results in higher maternal prolactin levels that enter foetal circulation and bind to putative foetal prolactin receptors to inhibit hair follicle growth. In this way, increasing levels of maternal prolactin production is potentially transmitted to the developing foetus through the utero-placental unit. This, in turn, delivers a time of year message allowing the foetus to develop with reduced hair density in anticipation of a warmer summer climate. 


\section{Conclusions}

The observations made in the described studies suggest that foetal development and specific foetal physiological adaptations in anticipation of the environmental conditions at birth are primed by the light-dark cycle perceived by the pre-partum mare. How this is communicated is yet to be fully elucidated but likely involves endocrine and/or metabolic messengers crossing the placenta. Utero-placental communications in the mare require further investigations to better understand the specific mechanisms through which an extended photoperiod provided to the mare may serve to increase foal birth weight, impact foal coat at birth and, possibly, reduce gestation length. An important area for further study is to determine what other aspects of foetal developmental physiology are influenced by the photoperiodic stimulus perceived by the mare.

\section{Authorship}

Barbara A. Murphy contributed substantially to the conception and design of the studies. Caroline M. Walsh, Noelle Duff and Conor McCrarren contributed substantially to the acquisition of data. Margaret B. Nolan and Barbara A. Murphy contributed substantially to the analysis and interpretation of data. Margaret B. Nolan and Barbara A. Murphy contributed substantially to the drafting of the manuscript and all authors approved the final version submitted. 


\section{Funding}

Study 2 was supported by an Enterprise Ireland Commercialisation Fund grant to B. A. Murphy.

\section{Acknowledgements}

The authors acknowledge the management and staff at the University of Kentucky's Maine Chance Farm in Lexington, KY, the Irish National Stud in Co. Kildare, Ireland, Professor Mats Troedsson at the Gluck Equine Research Centre, University of Kentucky and Equilume Ltd, Kildare, Ireland for contribution of mobile light masks.

\section{Declarations of interest}

B.A. Murphy is a member of the Board of Directors for Equilume Ltd.

\section{References}

[1] Nagy P, Guillaume D, Daels P. Seasonality in mares. Animal Reproduction Science 2000; 60: $245-62$

[2] Hughes JP, Stabenfeldt GH, Evan JW. The oestrous cycle of the mare. J Reprod Fertil Suppl 1975; 23: 161-6.

[3] Palmer E, Driancourt M, Ortavant R. Photoperiodic stimulation of the mare during winter anoestrus. Journal of reproduction and fertility Supplement 1982; 32: 275.

[4] Burkhardt J. Transition from anoestrus in the mare and the effects of artificial lighting. The Journal of Agricultural Science 1947; 37: 64-8. 
[5] Palmer E, Guillaume D. Photoperiodism in the equine species--what is a long night? Animal Reproduction Science 1992; 28: 21-30.

[6] Shabpareh V, Squires EL, Cook VM. An alternative artificial lighting regime to hasten the onset of the breeding season in mares. Equine Practice 1992; 14(2): 24-7

[7] Dicks P, Russel AGF, Lincoln GA. The role of prolactin in the reactivation of hair follicles in relation to moulting in cashmere goats. Journal of Endocrinology 1994; 143: 441-8.

[8] Walsh CM, Prendergast RL, Sheridan JT, Murphy BM. Blue light from light emitting diodes directed at a single eye elicits a dose-dependent suppression of melatonin in horses. The Veterinary Journal 2013; 196: 231-5.

[9] Murphy BA, Walsh CM, Woodward EM, Prendergast RL, Ryle JP, Fallon LH, Troedsson MHT. Blue light from individual light masks directed at a single eye advances the breeding season in mares. Equine Veterinary Journal 2014; 46: 601-5.

[10] Amoah E A, Gelaye S, Guthrie P, Rexroad, CE. Breeding season and aspects of reproduction of female goats. Journal of Animal Science 1996; 74: 723-8.

[11] García AJ, Landete-castillejos T, Carrión D, Gaspar-lópez E, Gallego L. Compensatory extension of gestation length with advance of conception in red deer (Cervus elaphus). Journal of Experimental Zoology Part A: Comparative Experimental Biology 2006; 305A: 55-61.

[12] Scott IC, Asher GW, Archer JA, Littlejohn RP. The effect of conception date on gestation length of red deer (Cervus elaphus). Animal Reproduction Science 2008; 109: 206-17.

[13] Hintz HF, Hintz RL, Van Vleck LD. Growth rate of Thoroughbreds. Effect of age of dam, year and month of birth, and sex of foal. Journal of Animal Science 1979; 48: 480-7.

[14] Pérez CC, Rodríguez I, Mota, J, Dorado J, Hidalgo M, Felipe M, et al. Gestation length in Carthusian Spanishbred mares. Livestock Production Science 2003; 82: 181-7.

[15] Valera M, Blesa F, Santos R D, Molina A. Genetic study of gestation length in Andalusian and Arabian mares. Animal reproduction science 2006; 95: 75-96. 
[16] Walton A, Hammond J. The maternal effects on growth and conformation in Shire horseShetland pony crosses. Proceedings of the Royal Society of London. Series B Biological Sciences 1938; 125: 311-35.

[17] Astudillo CR, Hajek GE, Diaz OH. Influencia de algunos factores climaticos sobre la duracion de la gestacion de yeguas fina sangre de carrera: estudio preliminar. Zoolatria 2 1960; $37-8$.

[18] Giger R, Meier HP, Küpfer U. Length of gestation of Freiberger mares with mule and horse foals. Schweiz Arch Tierheilkd 1997; 139: 303-7.

[19] Hodge SL, Kreider JL, Potter GD, Harms PG, Fleeger JL. Influence of photoperiod on the pregnant and postpartum mare. American Journal of Vet Research 1982; 43: 1752-5.

[20] Rowell J, Shipka M. Variation in gestation length among captive reindeer (Rangifer tarandus tarandus). Theriogenology 2009; 72: 190-7.

[21] Pool-Anderson K, Raub RH, Warren JA. Maternal influences on growth and development of full-sibling foals. Journal of Animal Science 1994; 72: 1661-6.

[22] Davies Morel MCG, Newcombe JR, Holland SJ. Factors affecting gestation length in the Thoroughbred mare. Animal Reproduction Sc 2002; 74: 175-85.

[23] Satué K, Felipe M, Mota J, Muñoz A. Factors influencing gestational length in mares: A review. Livestock Science 2011; 136: 287-94.

[24] Wilsher S, Allen WR. The effects of maternal age and parity on placental and foetal development in the mare. Equine Veterinary Journal 2003; 35: 476-83.

[25] Reppert SM, Duncan MJ, Duncan BD. Photic influences on the developing mammal. In: Evered D, Clark S, editors. CIBA Foundation Symposium Photoperiodism, Melatonin and the Pineal, London: Pitman Publishing; 1985, p. 116-28.

[26] Torres-Farfan C, Valenzuela FJ, Mondaca M, Valenzuela GJ, Krause B, Herrera EA et al. Evidence of a role for melatonin in foetal sheep physiology: direct actions of melatonin on foetal cerebral artery, brown adipose tissue and adrenal gland. J Physiol 2008; 586: 4017-27. 
[27] Williams LM, Hannah LT, Adam CL, Bourke DA. Melatonin receptors in red deer foetuses (Cervus elaphus). Journal of Reproduction and Fertility 1997; 110: 145-51.

[28] LeRoith D, Bondy C, Yakar S, Liu JL, Butler A. The somatomedin hypothesis. Endocrine Reviews 2001; 22: 53-74.

[29] Suttie JM, White RG, Breier BH, Gluckman PD. Photoperiod associated changes in insulinlike growth factor-1 in reindeer. Endocrinology 1991; 129(2): 679-82

[30] Champion ZJ, Breier BH, Ewen WE, Tobin TT, Casey PJ. Blood plasma concentrations in insulin-like growth factor (IGF-1) in resting Standardbred horses. The Veterinary Journal 2002; 163: 45-50.

[31] Yakar S, Rosen CJ, Beamer WG, Ackert-Bicknell CL, Wu Y, Liu JL et al. Circulating levels of IGF-1 directly regulate bone growth and density. Journal of Clinical Investigation 2002; 110: $771-4$.

[32] Malinowski K, Christensen RA, Hafs HD, Scanes CG. Age and breed differences in thyroid hormones insulin-like growth factor (IGF)-1 and IGF binding proteins in female horses. Journal of Animal Science 1996; 74: 1936-42.

[33] Cymbaluk NF, Laarveld B. The ontogeny of serum insulin-like factor 1 concentration in foals: effects of dam parity, diets, and age at weaning. Domestic Animal Endocrinology 1996; 13: 1247-50.

[34] Staniar WB, Kronfeld DS, Akers RM, Harris PA. Insulin-like growth factor 1 in growing Thoroughbreds. Journal of Animal Physiology and Animal Nutrition 2007; 91: 390-9.

[35] Ma L, Burton KA, Saunders JC, Dauncey MJ. Thermal and nutritional influences on tissue levels of insulin-like growth factor-1 mRNA and peptide. Journal of Thermal Biology 1992; 17: 89-95.

[36] Sarko TA, Bishop MD, Davis ME. Relationship of air temperature, relative humidity, precipitation, photoperiod, wind speed and solar radiation with serum insulin-like growth factor I (IGF-I) concentrations in Angus beef cattle. Domestic Animal Endocrinology 1994; 11: 281-90. 
[37] Lincoln GA, Rhind SM, Pompolo S, Clarke IJ. Hypothalamic control of photoperiod-induced cycles of food intake, body weight, and metabolic hormones in rams. American Journal of Regulatory Integrative and Comparative Physiology 2001; 281: 76-90.

[38] Munoz A, Trigo C, Riber C, Malonda V, Castejon F. A study of serum insulin-like growth factor type 1 (IGF-1) concentrations in resting untrained Andalusian horses: influence of age and gender. Veterinarni Medicina 2011; 56: 231-42.

[39] Valcavi R, Zine M, Maestroni GJ, Conti A, Portioli I. Melatonin stimulates growth hormone secretion through pathways other than the growth hormone releasing hormone. Clinical Endocrinology 1993; 39: 193-9.

[40] Fitzgerald BP, Davison LA, McManus CJ. Evidence for a seasonal variation in the ability of exogenous melatonin to supress prolactin secretion in the mare. Domestic Animal Endocrinology 2000; 18: 395-408.

[41] Gebbie FE, Forsyth AA, Arendt J. Effects of maintaining solstice light and temperature on reproductive activity, coat growth, plasma prolactin and melatonin in goats. Journal of Reproduction and Fertility 1999; 116: 25-33.

[42] Johnston B, Rose J. Role of prolactin in regulating the onset of winter fur growth in mink: A reconsideration. Journal of Experimental Zoology 1999; 284: 437-44.

[43] Smale L, Lee TM, Nelson RJ, Zucker I. Prolactin counteracts effects of short day lengths on pelage growth in the meadow vole, Microtus pennsylvanicus. Journal of Experimental Zoology 1990; 253: $186-8$.

[44] Freemark M, Kirk K, Pihoker C, Robertson MC, Shiu RPC, Driscoll P. Pregnancy lactogens in the rat conceptus and foetus: circulating levels, distribution of binding, and expression of receptor messenger ribonucleic acid. Endocrinology 1993; 133: 1830-42.

[45] Ogren L, Talamantes F. Prolactins of pregnancy and their cellular source. Int Rev Cytol 1988; 112: 1-65. 
[46] Nett TM, Holtan DW, Estergreen VL. Oestrogens, LH, PMSG, and prolactin in serum of pregnant mares. Journal of Reproduction and Fertility. Supplement 1975; 23: 457-62.

[47] Evans MJ, Alexander SL, Irvine CHG, Livesey JH, Donald RA. In vitro and in vivo studies of equine prolactin secretion throughout the year, Journal of Reproduction and Fertility 1991; 44: 27-35.

[48] O'Callaghan D, Karsch FJ, Boland MP, Roche JF. What photoperiodic signal is provided by a continuous release melatonin implant? Biology of Reproduction 1991; 45: 927-33.

[49] Poulton AL, English J, Symons AM, Arendt J. Effects of various melatonin treatments on plasma prolactin concentrations in the ewe. Journal of Endocrinology 1986; 108: 287-92.

[50] Murphy BA, Martin AM, Furney P, Elliot JA. Absence of a serum melatonin rhythm under acutely extended darkness in the horse. Journal of Circadian Rhythms 2011; 9: 3.

[51] Foitzik K, Krause K, Conrad F, Nakamura M, Funk W, Paus R. Human scalp hair follicles are both a target and a source of Prolactin, which serves as an autocrine and/or paracrine promoter of apoptosis-driven hair follicle regression. American Journal of Pathology 2006; 168(3): 748-56.

[52] Seyoum G, Robertson MC, Persaud TV, Paterson JA, Shiu RP. Influence of rat placental lactogen-I on the development of whole rat embryos in culture. Journal of Endocrinology 1999; $161(2): 231-7$.

[53] Murphy BA, Elliot JA, Sessions DR, Vick MM, Kennedy EL, Fitzgerald BP. Rapid phase adjustment of melatonin and core body temperature rhythms following a $6 \mathrm{~h}$ advance of the light/dark cycle in the horse. Journal of Circadian Rhythms 2007; 5: 5. 


\section{Supplementary data}

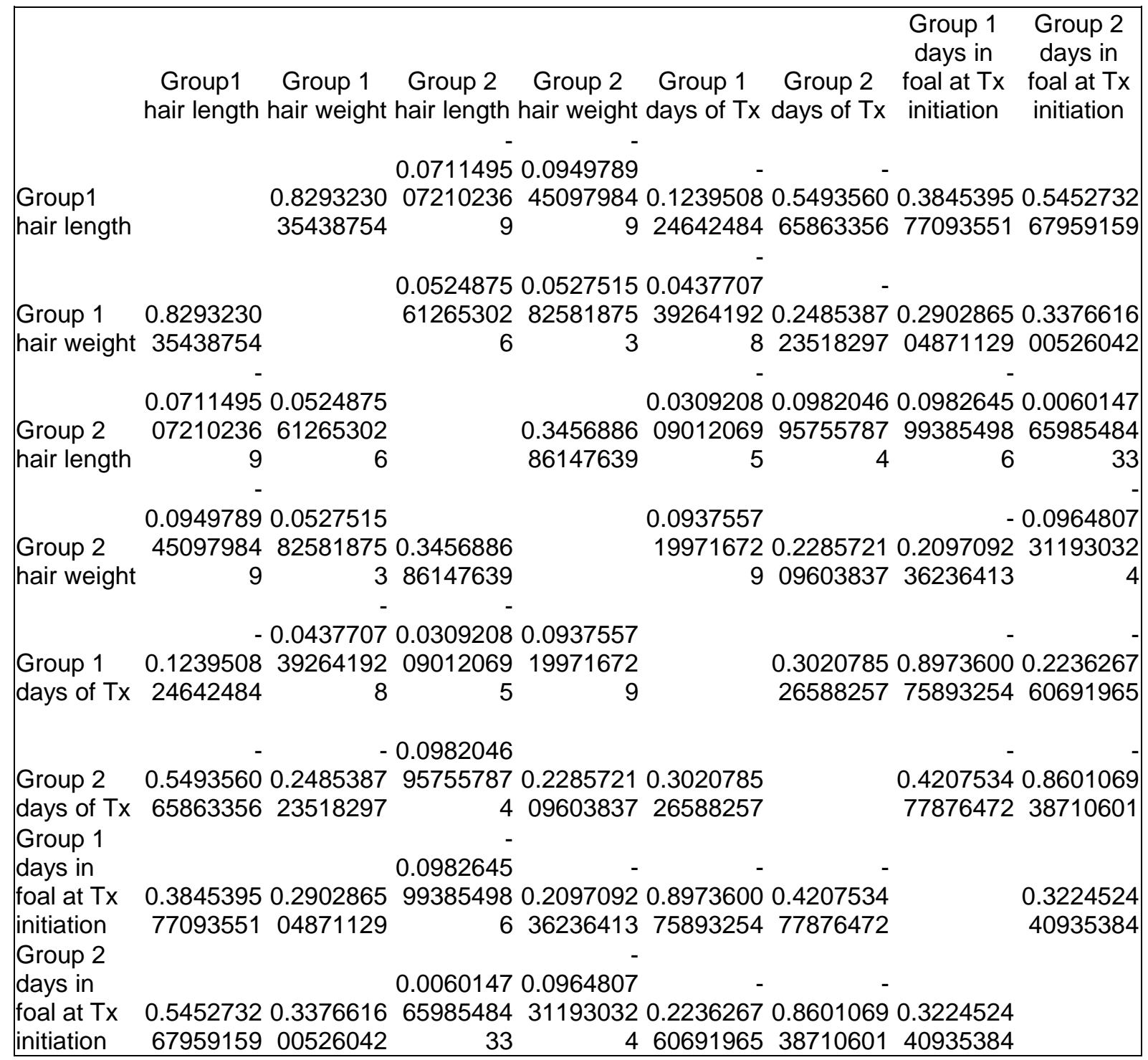

Pearson correlation ( $r$ ) co-efficient: Hair length, weight, days of treatment (Tx), days in foal at initiation of $\mathrm{Tx}$ 


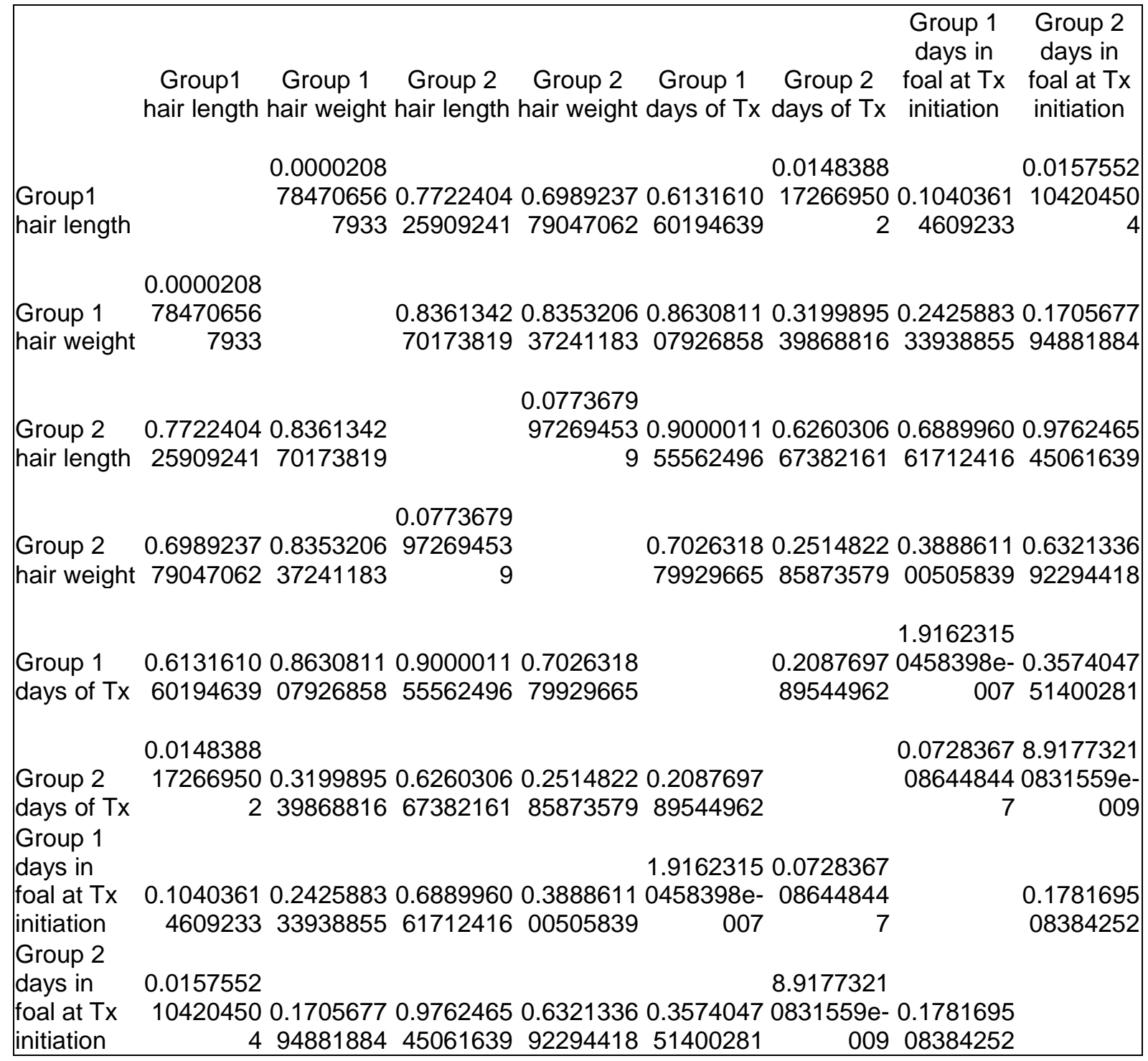

Pearson correlation ( $r$ ) co-efficient $P$ values: Hair length, weight, days of treatment (Tx), days in foal at initiation of $\mathrm{Tx}$ 


\begin{tabular}{|c|c|c|c|c|c|c|}
\hline & $\begin{array}{l}\text { Group1 hair } \\
\text { length }\end{array}$ & $\begin{array}{l}\text { Group } 1 \text { hair } \\
\text { weight }\end{array}$ & $\begin{array}{l}\text { Group } 2 \text { hair } \\
\text { length }\end{array}$ & $\begin{array}{l}\text { Group } 2 \text { hair } \\
\text { weight }\end{array}$ & Group 1 FBW & Group 2 FBW \\
\hline $\begin{array}{l}\text { Group1 hair } \\
\text { length }\end{array}$ & & $\begin{array}{r}0.829323035 \\
438754\end{array}$ & $\begin{array}{r}0.071149507 \\
2102369\end{array}$ & $\begin{array}{r}0.094978945 \\
0979849\end{array}$ & $\begin{array}{r}0.119513810 \\
161805\end{array}$ & $\begin{array}{r}0.156786771 \\
602776\end{array}$ \\
\hline $\begin{array}{l}\text { Group } 1 \text { hair } \\
\text { weight }\end{array}$ & $\begin{array}{r}0.829323035 \\
438754\end{array}$ & & $\begin{array}{r}0.052487561 \\
2653026\end{array}$ & $\begin{array}{r}0.052751582 \\
5818753\end{array}$ & $\begin{array}{r}0.216385970 \\
437947\end{array}$ & $\begin{array}{r}0.258340563 \\
560003\end{array}$ \\
\hline $\begin{array}{l}\text { Group } 2 \text { hair } \\
\text { length }\end{array}$ & $\begin{array}{r}0.071149507 \\
2102369\end{array}$ & $\begin{array}{r}0.052487561 \\
2653026\end{array}$ & & $\begin{array}{r}0.345688686 \\
147639\end{array}$ & $\begin{array}{r}0.408655254 \\
034256\end{array}$ & $\begin{array}{r}0.107511206 \\
599726\end{array}$ \\
\hline $\begin{array}{l}\text { Group } 2 \text { hair } \\
\text { weight }\end{array}$ & $\begin{array}{r}0.094978945 \\
0979849\end{array}$ & $\begin{array}{r}0.052751582 \\
5818753\end{array}$ & $\begin{array}{r}0.345688686 \\
147639\end{array}$ & & $\begin{array}{r}0.416048099 \\
96964\end{array}$ & $\begin{array}{r}0.095271520 \\
9741365\end{array}$ \\
\hline Group 1 FBW & $\begin{array}{r}0.119513810 \\
161805\end{array}$ & $\begin{array}{r}0.216385970 \\
437947\end{array}$ & $\begin{array}{r}0.408655254 \\
034256\end{array}$ & $\begin{array}{r}0.416048099 \\
96964\end{array}$ & & $\begin{array}{r}0.249448903 \\
98628\end{array}$ \\
\hline Group 2 FBW & $\begin{array}{r}0.156786771 \\
602776 \\
\end{array}$ & $\begin{array}{r}- \\
0.258340563 \\
560003 \\
\end{array}$ & $\begin{array}{r}0.107511206 \\
599726 \\
\end{array}$ & $\begin{array}{r}0 . \\
0.095271520 \\
9741365 \\
\end{array}$ & $\begin{array}{r}0.249448903 \\
98628 \\
\end{array}$ & \\
\hline
\end{tabular}

Pearson correlation ( $r$ ) co-efficient: Hair length, weight, foal birth weight (FBW)

\begin{tabular}{|c|c|c|c|c|c|c|}
\hline & $\begin{array}{l}\text { Group1 hair } \\
\text { length }\end{array}$ & $\begin{array}{l}\text { Group } 1 \text { hair } \\
\text { weight }\end{array}$ & $\begin{array}{l}\text { Group } 2 \text { hair } \\
\text { length }\end{array}$ & $\begin{array}{l}\text { Group } 2 \text { hair } \\
\text { weight }\end{array}$ & Group 1 FBW & Group 2 FBW \\
\hline $\begin{array}{l}\text { Group } \\
\text { lenath }\end{array}$ & & 0.000020878 & 0.772240425 & 0.698923779 & 0.647759004 & 0.534404316 \\
\hline length & & 4706567933 & 909241 & 047062 & 93095 & 22334 \\
\hline $\begin{array}{l}\text { Group } 1 \text { hair } \\
\text { weight }\end{array}$ & $\begin{array}{r}0.000020878 \\
4706567933\end{array}$ & & $\begin{array}{r}0.836134270 \\
173819\end{array}$ & $\begin{array}{r}0.835320637 \\
241183\end{array}$ & $\begin{array}{r}0.420855664 \\
393631\end{array}$ & $\begin{array}{r}0.316748394 \\
474125\end{array}$ \\
\hline $\begin{array}{l}\text { Group } 2 \text { hair } \\
\text { length }\end{array}$ & $\begin{array}{r}0.772240425 \\
909241\end{array}$ & $\begin{array}{r}0.836134270 \\
173819\end{array}$ & & $\begin{array}{r}0.077367997 \\
2694539\end{array}$ & $\begin{array}{r}0.103393284 \\
672352\end{array}$ & $\begin{array}{r}0.601141332 \\
05915\end{array}$ \\
\hline $\begin{array}{l}\text { Group } 2 \text { hair } \\
\text { weight }\end{array}$ & $\begin{array}{r}0.698923779 \\
047062\end{array}$ & $\begin{array}{r}0.835320637 \\
241183\end{array}$ & $\begin{array}{r}0.077367997 \\
2694539\end{array}$ & & $\begin{array}{r}0.096702514 \\
0958353\end{array}$ & $\begin{array}{r}0.643396556 \\
76825\end{array}$ \\
\hline Grou & 0.647759004 & $\begin{array}{r}0.420855664 \\
393631\end{array}$ & 0.103393284 & 0.096702514 & & 0.351489708 \\
\hline Group 2 FBW & $\begin{array}{r}0.534404316 \\
22334\end{array}$ & $\begin{array}{r}0.316748394 \\
474125\end{array}$ & $\begin{array}{r}0.601141332 \\
05915\end{array}$ & $\begin{array}{r}0.643396556 \\
76825\end{array}$ & $\begin{array}{r}0.351489708 \\
294454\end{array}$ & \\
\hline
\end{tabular}

Figure 4. Pearson correlation ( $r$ ) co-efficient $P$ values: Hair length, weight, foal birth weight (FBW) 